\title{
Sistem Rekomendasi Layanan Harga Produk Terendah Berbasis Partisipasi Masyarakat
}

\author{
Fany Ayu Anggreany ${ }^{\# 1}$, Yus Sholva ${ }^{* 2}$, Helen Sasty Pratiwi ${ }^{\# 3}$

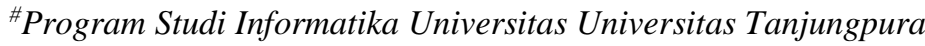 \\ Jl. Prof. Dr. H. Hadari Nawawi, Pontianak, Kalimantan Barat 78115 \\ layuanggreany@gmail . com \\ ${ }^{2}$ sholvarizaduntan.ac.id \\ 3helensastypratiwilgmail.com
}

\begin{abstract}
Abstrak - Pada era digital ini, semakin mudahnya internet dijangkau membuat perubahan pada perilaku belanja konsumen. Menurut Couponrani.com sebanyak 54\% konsumen memanfaatkan internet untuk membandingkan harga saat berada di dalam toko konvensional. Namun dalam membandingkan harga ditemui kendala yaitu sulitnya mendapatkan informasi harga produk pada toko konvensional. Meskipun toko konvensional ada beberapa yang menyediakan katalog harga produknya, tidak semua produk ditampilkan dalam katalog. Oleh karena itu, perlu dibuat aplikasi dengan sistem rekomendasi harga produk terendah menggunakan partisipasi masyarakat. Partisipasi masyarakat digunakan karena tidak adanya sumber yang memberikan data harga produk yang selalu terupdate sehingga diperlukan dukungan dari masyarakat yang memberikan data secara sukarela. Pada penelitian ini untuk membuat masyarakat ikut berpartisipasi memberikan data harga produk yaitu dengan membangun sistem rekomendasi ini dalam bentuk sebuah aplikasi catatan belanja. Catatan belanja yang dimasukkan oleh pengguna ke aplikasi akan disimpan dalam sebuah basis data sehingga dapat diakses oleh pengguna lain dalam bentuk rekomendasi harga terendah. Rekomendasi dihasilkan dengan memilah data harga produk terbaru dan terendah untuk kemudian diurutkan berdasarkan jumlah produk yang tersedia, total harga, dan jarak toko terdekat yang dihasilkan dengan melakukan perhitungan jarak antara pengguna dan toko menggunakan formula haversine. Berdasarkan hasil pengujian, aplikasi ini sudah berjalan dengan baik pada perangkat smartphone Android. Hasil perhitungan Likert's Summated Rating diperoleh nilai 1701 yang menerangkan bahwa aplikasi ini dapat dikategorikan dengan kriteria "Berhasil".
\end{abstract}

Kata kunci - rekomendasi, harga terendah, produk, partisipasi masyarakat, android

\section{Pendahuluan}

Pada era digital sekarang ini, internet semakin mudah dijangkau seiring dengan semakin meningkatnya pengguna internet dan smartphone di Indonesia. Berbagai aspek kehidupan tidak terlepas dari internet membuat perubahan pada perilaku belanja konsumen. Menurut
Media Konsumen [1], berdasarkan hasil survei di India yang dilakukan oleh couponrani.com dapat memberi gambaran bagaimana era digital telah mempengaruhi perilaku masyarakat dalam berbelanja. Meskipun survei tersebut dilakukan di India, secara umum perilaku konsumen Indonesia di era digital memiliki kecenderungan yang serupa. Hasil survei tersebut menunjukkan $92 \%$ konsumen memanfaatkan internet untuk mencari informasi produk sebelum melakukan keputusan pembelian di toko konvensional (offline). Sebanyak 54\% dari konsumen memanfaatkan internet untuk membandingkan harga, 18\% membandingkan produk yang diminati dengan produk sejenis yang lain, dan $20 \%$ membaca review atau feedback produk.

Kebutuhan untuk membandingkan harga produk dari satu tempat belanja dengan tempat belanja yang lain dikarenakan perilaku konsumen yang menginginkan produk dengan harga yang murah. Pada saat berbelanja jika harga suatu produk di toko yang sedang dikunjungi mahal, konsumen akan menunda membeli beberapa barang untuk dibeli di toko lain yang menjual produk tersebut dengan harga yang lebih murah. Kondisi ini menyebabkan belanja konsumen tidak efisien. Jika konsumen tetap membeli barang tersebut di toko yang sama dengan kondisi harga produk yang lebih mahal, maka akan menyebabkan ketidakpuasan tersendiri dari konsumen.

Namun ketika membandingkan harga produk ditemui kendala untuk mendapatkan informasi harga produk pada toko konvensional. Tidak semua toko bersedia memberikan informasi harga produknya. Hanya toko ritel berskala besar yang bersedia memberikan informasi harga produknya dalam bentuk katalog, sedangkan minimarket atau supermarket lokal hanya menyediakan label harga pada rak tokonya. Harga produk yang disediakan pada katalog juga hanya produk yang sedang promo atau diskon saja sedangkan produk lain yang sedang tidak diskon tidak ditampilkan. Selain itu harga produk pada katalog mempunyai periode waktu tertentu sehingga informasi akan usang. Kurangnya informasi harga produk 
menyebabkan konsumen sulit untuk membandingkan harga suatu produk pada satu tempat belanja dengan tempat belanja yang lainnya.

Selain itu, harga produk yang selalu berubah-ubah menjadi acuan diperlukannya sebuah aplikasi yang dapat melakukan pembaruan data. Salah satu metode yang dapat dipakai untuk mendapat informasi harga terbaru suatu produk yaitu melalui partisipasi masyarakat. Partisipasi masyarakat dalam penelitian ini digunakan sebagai konsep dalam membangun aplikasi sehingga aplikasi yang dihasilkan dapat menghimpun data dari pengguna. Partisipasi masyarakat digunakan karena tidak ada toko konvensional yang bersedia memberikan informasi harga produknya sehingga masyarakat sendirilah yang harus memberikan data. Dalam menghimpun data dari masyarakat, diperlukan sebuah cara agar masyarakat memberikan data harga yang benar yaitu dengan membangun sistem rekomendasi layanan harga produk terendah ini dalam bentuk sebuah aplikasi catatan belanja.

Selain digunakan agar masyarakat memberikan data yang benar, catatan belanja juga merupakan sebuah cara untuk membuat aplikasi ini dibutuhkan oleh masyarakat agar masyarakat tertarik untuk ikut berpartisipasi dalam memberikan harga produk. Jika banyak masyarakat yang berpartisipasi melakukan pencatatan belanjanya pada aplikasi maka dapat dihimpun data belanja yang dilakukan orang lain juga sehingga informasi harga merupakan harga yang ter-update. Melalui catatan belanja yang dikumpulkan dari banyak pengguna maka akan dapat dibandingkan harga produk dari satu tempat belanja dengan tempat belanja lain yang dapat membantu pengguna mendapatkan rekomendasi tempat belanja dengan harga produk yang terendah. Selain itu, dapat diketahui harga-harga produk sehingga konsumen dapat membuat rencana belanja dengan perkiraan jumlah uang yang akan dikeluarkan pada saat berbelanja.

Berdasarkan penjelasan yang telah dipaparkan, maka perlu dilakukan pengembangan aplikasi catatan belanja yang dapat membantu masyarakat mendapatkan informasi harga produk terendah dengan dukungan partisipasi masyarakat.

\section{URAIAN PENELITIAN}

\section{A. Catatan Belanja}

Catatan belanja merupakan daftar barang yang ingin dibeli ketika akan pergi berbelanja yang ditulis pada sebuah kertas [2]. Catatan belanja memiliki berbagai fungsi. Salah satu fungsi catatan belanja yaitu dapat digunakan sebagai mengatur anggaran belanja, atau untuk perencanaan belanja. Catatan belanja juga dapat menunjukkan kebutuhan atau ketertarikan konsumen [3]. Dalam menghimpun data dari masyarakat, diperlukan sebuah cara agar masyarakat memberikan data harga yang benar yaitu dengan membangun sistem rekomendasi layanan harga produk terendah ini dalam bentuk sebuah aplikasi catatan belanja.

\section{B. Partisipasi Masyarakat}

Dilihat dari segi etimologi, kata partisipasi berasal dari bahasa Inggris participate yang artinya mengikutsertakan, ikut mengambil bagian [4]. Partisipasi juga berarti peran serta seseorang atau kelompok masyarakat secara aktif dari proses perumusan kebutuhan, perencanaan, sampai pada tahap pelaksanaan kegiatan baik melalui pikiran atau langsung dalam bentuk fisik [5].

Dalam penelitian ini masyarakat turut berpartisipasi dengan melakukan pencatatan belanjaannya dari data struk belanja. Dari catatan belanja masyarakat, dapat diketahui harga produk dari toko-toko yang dikunjungi masyarakat. Informasi mengenai harga produk yang tidak statis dan dapat mengalami perubahan harga dan diskon barang di toko tertentu menjadi informasi yang sangat dibutuhkan konsumen ketika merencanakan belanjanya. Partisipasi masyarakat dalam penelitian ini digunakan sebagai konsep dalam membangun aplikasi sehingga aplikasi yang dihasilkan dapat menghimpun data dari pengguna. Partisipasi masyarakat digunakan karena tidak ada toko konvensional yang bersedia memberikan informasi harga produknya sehingga masyarakat sendirilah yang harus memberikan data. Informasi mengenai harga dan diskon produk diperlukan melalui partisipasi masyarakat untuk membantu menjadikan aplikasi yang dikembangkan peneliti menjadi aplikasi dengan harga produk yang selalu ter-update dan dapat membantu memberikan informasi yang jelas dan berguna untuk konsumen.

\section{Barcode Scanner}

Barcode Scanner adalah suatu alat yang digunakan untuk membaca kode-kode bar. Kode bar terdapat pada tanda pengenal produk. Penggunaan barcode scanner dapat memperkecil kesalahan input yang disebabkan kesalahan operator komputer atau kasir. Penggunaan barcode scanner juga dapat mempercepat proses memasukkan data [6]. Pada penelitian ini barcode scanner digunakan dengan tujuan agar pengguna tidak perlu mengetik nama produk ketika menginput data nota belanja pada aplikasi. Beberapa jenis barcode yang standar dan diakui untuk retail yaitu EAN-13 yang digunakan sebagai standar kode batang retail di Eropa dan seluruh dunia kecuali Amerika dan Kanada [7], EAN-8, dan UPC.

Pada android studio untuk menambahkan barcode scanner pada aplikasi yang dibangun menggunakan library dari Avaneesh Maurya yang dibangun dengan menggunakan barcode detector pada Google Mobile Vision API. Barcode detector pada Mobile Vision API dapat mendeteksi barcode secara real time dalam segala orientasi. Format barcode yang dapat dibaca oleh API yaitu EAN-13, EAN-8, Code-39, Code-93, Code-128, UPC-A, UPC-E, ITF, dan Codabar.

Barcode scanner ditambahkan dengan cara memasukkan library barcode scanner pada project. Kemudian karena library yang digunakan memerlukan Google Mobile Vision API maka perlu ditambahkan 
terlebih dahulu dengan cara menambahkan dependency pada project aplikasi [8].

\section{RESTful Web Service}

REST atau Representational State Trasnfer merupakan salah satu jenis web service yang pertama kali diperkenalkan pada tahun 2000 oleh Roy Fielding [9]. REST merupakan standar dalam arsitektur web yang menggunakan protocol HTTP untuk pertukaran data [10]. Web service adalah salah satu bentuk sistem perangkat lunak yang didesain untuk mendukung interaksi mesin ke mesin melalui jaringan [11]. Sistem web service memungkinkan sebuah fungsi yang ada di dalam web service dapat digunakan oleh aplikasi lain tanpa perlu mengetahui detail pemrograman yang terdapat didalamnya. Contoh implementasi dari web service antara lain adalah SOAP dan REST. Sistem yang menggunakan arsitektur dari REST dapat disebut dengan RESTful Web service [12].

Cara kerja dari RESTful web service yaitu client mengirimkan sebuah data atau request melalui HTTP request dan kemudian server merespon melalui HTTP response. Komponen dari HTTP request yaitu:

- HTTP method yang digunakan misalnya GET, POST, PUT, DELETE.

- Uniform Resource Identifier (URI) untuk mengidentifikasi lokasi resource pada server.

- HTTP Version, menunjukkan versi dari HTTP yang digunakan, contoh HTTP v1.1.

- $\quad$ Request Header, berisi metadata untuk HTTP request seperti type client/browser, format yang didukung oleh client, format dari body pesan.

- Request body, berisi konten dari data.

Sedangkan komponen dari HTTP response yaitu:

- Status/Response Code, mengindikasikan status server terhadap resource yang diminta.

- Response Header, berisi metadata untuk HTTP Response seperti tipe server, panjang konten, tipe konten, dan waktu response.

- Response Body, berisi konten dari data yang diberikan.

\section{E. Formula Haversine}

Formula Haversine adalah persamaan yang digunakan dalam navigasi. Formula Haversine merupakan suatu metode untuk mengetahui jarak antar dua titik dengan memperhitungkan bahwa bumi bukanlah sebuah bidang datar namun seperti hukum haversine yang berdasarkan bentuk bumi yang bulat (spherical earth) dengan menghilangkan faktor bahwa bumi sedikit elips (elipsodial factor). Formula ini merupakan bentuk persamaan khusus trigonometri bola, hukum haversine, yang mencari hubungan sisi dan sudut pada segitiga dalam bidang bola [13].

Formula Haversine masih dianggap baik untuk perhitungan numeris, bahkan untuk permukaan yang kecil. Berikut merupakan Rumus Haversine yang dipublikasikan oleh Roger Sinnott pada majalah Sky \& Telescope pada tahun 1984 ("Virtues of the Haversine") [14].

$$
\begin{aligned}
& \Delta \text { lat }=\text { lat2-lat1 } \\
& \Delta \operatorname{lng}=\operatorname{lng} 2-\operatorname{lng} 1 \\
& \mathrm{a}=\sin ^{2}(\Delta \mathrm{lat} / 2)+\cos (\text { lat } 1) * \cos (\text { lat } 2) * \sin ^{2}(\Delta \operatorname{lng} / 2) \\
& c=2 \cdot \operatorname{atan} 2(\sqrt{a}, \sqrt{ }(1-a)) \\
& \mathrm{d}=\mathrm{R} \cdot \mathrm{c} \\
& \text { Keterangan : } \\
& \mathrm{R} \quad=\text { jari-jari bumi sebesar 6371 }(\mathrm{km}) \\
& \Delta \text { lat }=\text { besaran perubahan latitude } \\
& \Delta \operatorname{lng}=\text { besaran perubahan longitude } \\
& \text { c = kalkulasi perpotongan sumbu } \\
& \mathrm{d} \quad=\text { jarak }(\mathrm{km})
\end{aligned}
$$

\section{F. Google Places API}

Google Places API memungkinkan pengguna untuk mengirimkan query untuk informasi tempat pada berbagai kategori, seperti perusahaan, lokasi geografis, dan banyak lagi. Layanan ini menggunakan HTTP requests untuk memberikan informasi berbagai tempat. Google Places API memungkinkan untuk melakukan pencarian tempat terdekat maupun pencarian berdasarkan teks [15].

Permintaan pencarian untuk tempat dengan jenis groceries dalam radius $500 \mathrm{~m}$ dari Gedung Informatika Untan, Pontianak, yang berisi kata market dalam nama tempat yang dicari dengan menggunakan HTTP request ke Google Places API sebagai berikut: https://maps.googleapis.com/maps/ api/place/nearbysearch/json?

location $=-$ $0.055623,109.348594$

\&radius $=500 \&$ type $=$ groceries $\&$ keyword $=$ market $\&$ key $=\mathrm{A}$ PI_KEY. Pada penelitian ini titik lokasi untuk melakukan request pencarian akan diambil dengan menggunakan Current Place pada Places SDK untuk dikirimkan pada permintaan terdekat.

\section{G. Google Places SDK For Android}

Places SDK untuk Android memungkinkan pengembang aplikasi untuk membangun location-aware apps yang merespon secara kontekstual terhadap bisnis lokal dan berbagai tempat lain yang ada disekitar perangkat. Beberapa fitur yang disediakan oleh Places SDK untuk android yaitu Places yang menyediakan akses ke basis data Google tentang tempat-tempat lokal dan informasi bisnis serta lokasi perangkat sekarang melalui kode program dan Autocomplete yang menyediakan widgets untuk menampilkan prediksi tempat sebagai respon dari kueri pencarian oleh user [16].

Place Picker adalah suatu fitur yang memungkinkan pengguna bisa melihat tempat-tempat yang ada disekitar lokasi pengguna. Cara kerja place picker yaitu dengan menggunakan interface UI yang sudah disediakan oleh Google, kemudian menggunakan intent untuk menjalankan fungsi place picker. Ketika dijalankan, place picker akan mendeteksi koordinat lokasi pengguna dan kemudian menampilkan lokasi-lokasi lain yang berada disekitar pengguna. Setelah itu pengguna dapat memilih satu lokasi tertentu dan mengambil data lokasi yang 
dipilih tersebut. Pada penelitian ini place picker digunakan pada aplikasi untuk memudahkan pengguna aplikasi memasukkan informasi tempat belanja ketika membuat catatan belanja.

\section{H. Unified Modelling Language}

Untuk membantu dalam pengembangan perangkat lunak dikenal istilah pemodelan. Salah satu pemodelan yang saat ini paling banyak digunakan oleh pengembang perangkat lunak adalah UML (Unified Modelling Language). UML adalah standar bahasa yang sering digunakan dalam bidang industri untuk mendefinisikan requirement (kebutuhan), membuat analisis dan desain, serta menggambarkan arsitektur dalam pemrograman berorientasi objek [17].

1. Use Case Diagram

Use case diagram merupakan pemodelan untuk kelakuan (behaviour) sistem yang akan dibuat. Use case mendeskripsikan sebuah interaksi antara satu atau lebih aktor dengan sistem yang akan dibuat. Use case digunakan untuk mengetahui fungsi apa saja yang ada di dalam sebuah sistem dan siapa saja yang berhak menggunakan fungsi-fungsi tersebut [17].

2. Activity Diagram

Diagram aktivitas atau activity diagram menggambarkan workflow (aliran kerja) atau aktivitas dari sebuah sistem atau proses bisnis atau menu yang ada pada perangkat lunak. Perlu diperhatikan bahwa diagram aktivitas menggambarkan aktivitas sistem bukan apa yang dilakukan aktor, jadi aktivitas yang dapat dilakukan oleh sistem [17].

3. Class Diagram

Diagram kelas atau class diagram menggambarkan struktur sistem dari segi pendefinisian kelas-kelas yang akan dibuat untuk membangun sistem. Kelas memiliki apa yang disebut atribut dan method atau operasi. Atribut merupakan variabel-variabel yang dimiliki oleh suatu kelas. Operasi atau method adalah fungsi-fungsi yang dimiliki oleh suatu kelas [17].

4. Sequence Diagram

Diagram sekuen menggambarkan kelakuan objek pada use case dengan mendeskripsikan waktu hidup objek dengan message yang dikirimkan dan diterima antar objek. Menggambarkan diagram sekuen harus diketahui objek-objek yang terlibat dalam sebuah use case beserta metode-metode yang dimiliki kelas yang diinstansiasi menjadi objek itu [17].

\section{PERANCANGAN SiSTEM}

\section{A. Perancangan Arsitektur Sistem}

Adapun arsitektur sistem yang akan dibangun dapat dilihat pada Gambar 1.

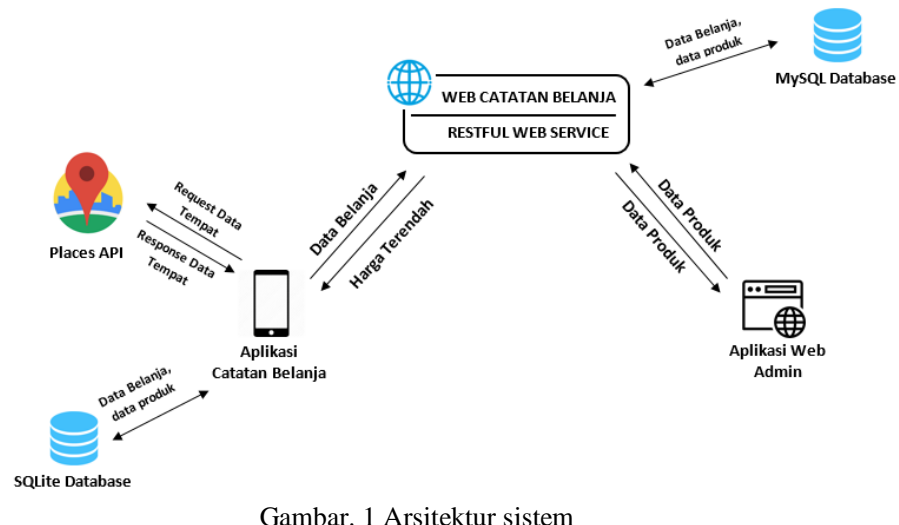

Berdasarkan Gambar. 1 proses yang terjadi yaitu masyarakat yang menggunakan aplikasi catatan belanja akan membuat catatan hasil belanjaan dari struk belanja yang diterima dari tempat belanja. Ketika menginputkan tempat belanja aplikasi akan melakukan request ke Places API dan akan memberikan response data tempat berupa JSON untuk ditampilkan pada maps atau ditampilkan dalam bentuk list yang dapat dipilih oleh pengguna. Semua item produk diinputkan beserta barcode produk, nama produk, dan harganya. Kemudian data catatan belanja tersebut disimpan ke dalam basis data SQLite yang berfungsi sebagai penyimpanan lokal. Kemudian jika terhubung ke internet, catatan belanja akan disimpan ke MySQL database pada server dan dapat diakses oleh pengguna lain melalui aplikasi dengan melakukan request ke server dan server akan memberikan response data harga terendah berupa JSON untuk kemudian ditampilkan oleh aplikasi. Jika banyak masyarakat yang melakukan pencatatan belanja pada aplikasi, maka akan terhimpun data produk beserta harganya. Dengan demikian konsep partisipasi masyarakat dapat menghasilkan data produk dengan informasi harga terbaru.

Web catatan belanja yang ditampilkan pada web browser merupakan sebuah admin panel yang digunakan sebagai pengelola data produk yang digunakan pada aplikasi untuk memudahkan pengguna dalam menambahkan item catatan belanja.

\section{B. Use Case Diagram}

Berikut merupakan use case diagram (Gambar 2) dari sistem rekomendasi layanan harga produk terendah.

\section{Entity Relationship Diagram}

Entity Relationship Diagram merupakan suatu teknik grafis yang menggambarkan skema basis data. Diagram ini terdiri dari sekumpulan objek dan relasi antar objek tersebut, serta dapat digunakan untuk menggambarkan relasi antara dua entitas atau lebih [18]. Secara umum gambaran basis data yang akan dibuat dapat dilihat pada Gambar 3. 


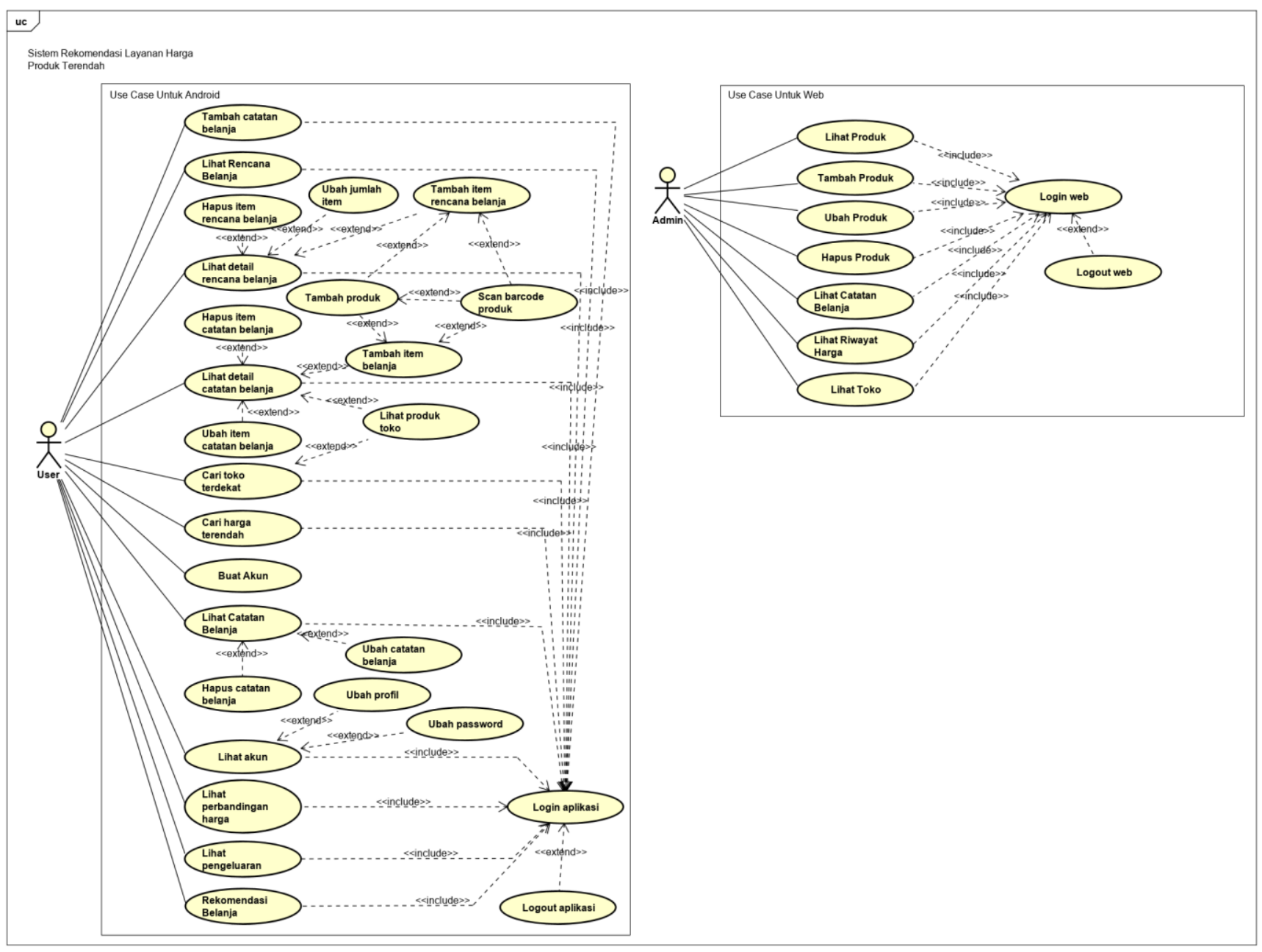

Gambar. 2 Use case diagram

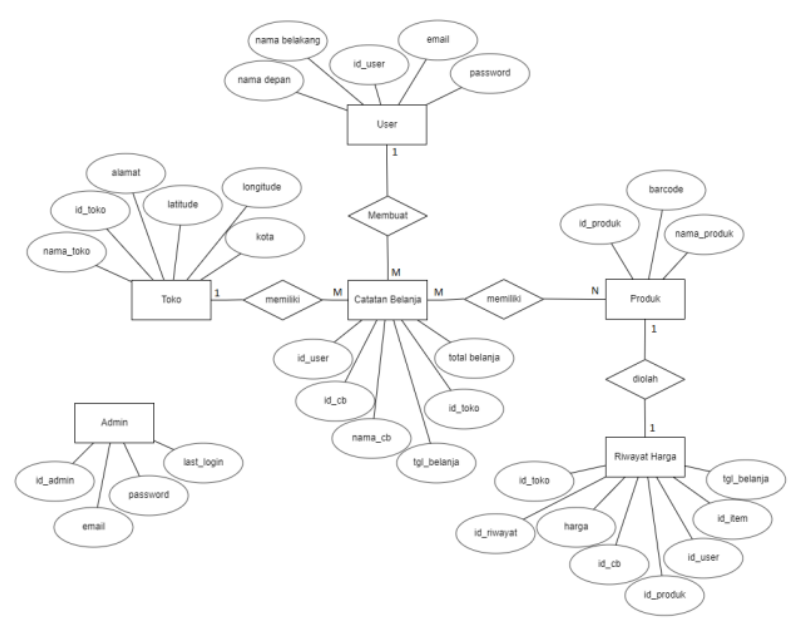

Gambar. 3 Entity relation diagram sistem

\section{Struktur Antarmuka Sistem}

Antarmuka merupakan tampilan dari suatu program aplikasi yang berperan sebagai sarana interaksi antara program dengan user.

\section{Gambar. 4 Struktur antarmuka sistem}

\section{E. Hasil Perancangan}

Sistem yang dihasilkan merupakan aplikasi catatan belanja yang dapat menghasilkan rekomendasi harga produk terendah berbasis Android yang dibangun menggunakan Android Studio dengan bahasa pemrograman java dan sebuah website admin untuk mengelola data master produk. Dalam implementasinya, aplikasi catatan belanja dilengkapi dengan barcode scanner untuk memudahkan pengguna menginput produk pada catatan belanjanya. Aplikasi ini dibangun dalam bentuk aplikasi catatan belanja agar masyarakat memberikan data harga yang benar dan memudahkan masyarakat dalam mendapatkan rekomendasi belanja dengan harga terendah yang dapat diseleksi dan diurutkan berdasarkan ketersediaan produk, total belanja terendah, 
atau toko terdekat sesuai keinginan pengguna. Berikut beberapa tampilan hasil perancangan sistem.

Gambar 4 merupakan halaman dashboard admin yang dapat diakses oleh admin setelah login. Admin dapat mengelola data master produk dan melihat data yang sudah ditambahkan dengan memilih menu yang ada pada sidebar.

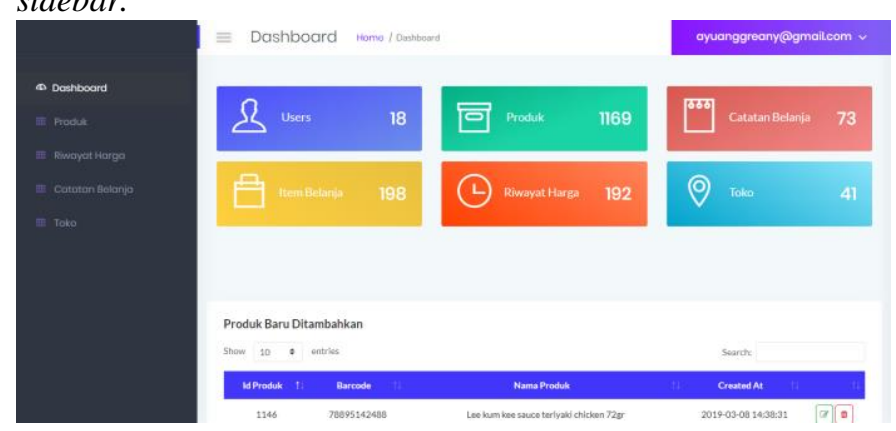

Gambar. 4 Halaman dashboard website admin

Gambar 5 merupakan tampilan menu utama pada aplikasi yang terletak pada bottom navigation view terdapat 5 menu utama yaitu catatan, rekomendasi, bantuan, cari, dan akun.

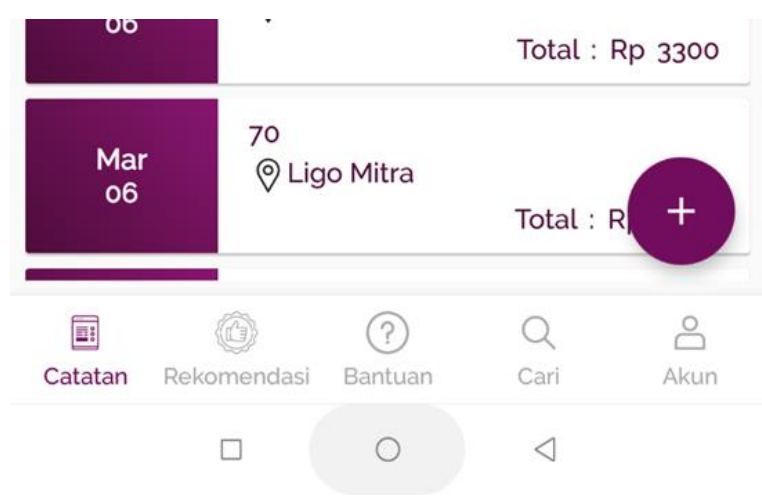

Gambar. 5 Antarmuka menu utama

Gambar 6 merupakan tampilan catatan belanja pada aplikasi. Pengguna dapat membuat catatan belanja baru dengan menekan tombol tambah dan membuka catatan dengan memilih salah satu catatan yang sudah dibuat untuk menambahkan item belanja.

Gambar 7 merupakan tampilan rencana belanja pada aplikasi. Pengguna dapat membuat rencana belanja baru dengan menekan tombol tambah dan membuka catatan dengan memilih salah satu rencana yang sudah dibuat untuk menambahkan item belanja.

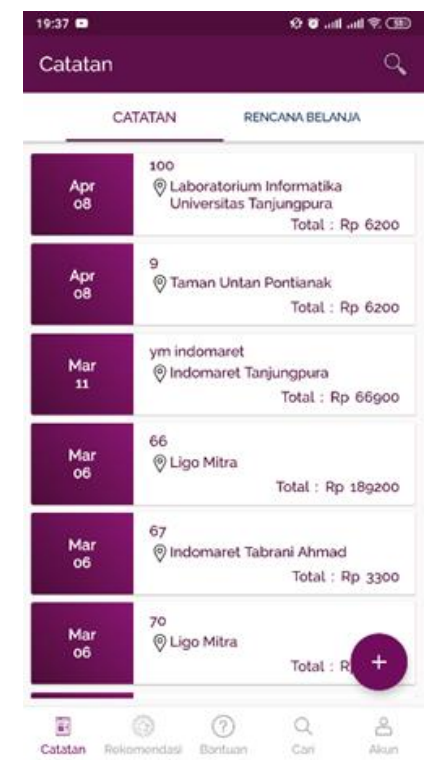

Gambar. 6 Antarmuka catatan belanja
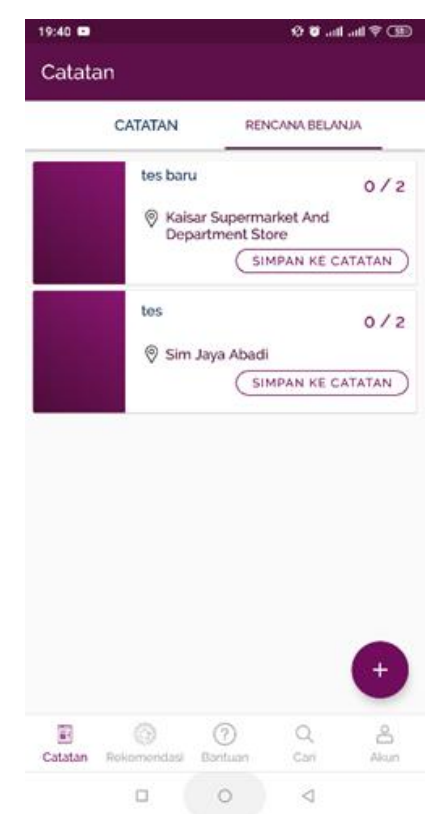

Gambar. 7 Antarmuka rencana belanja

Gambar 8 merupakan tampilan detail rencana belanja. Pada halaman ini pengguna dapat menambahkan item belanja dan melihat rekomendasi setelah menambahkan item belanja. Rekomendasi juga dapat dilihat dengan cara memilih menu rekomendasi pada Gambar 5. 


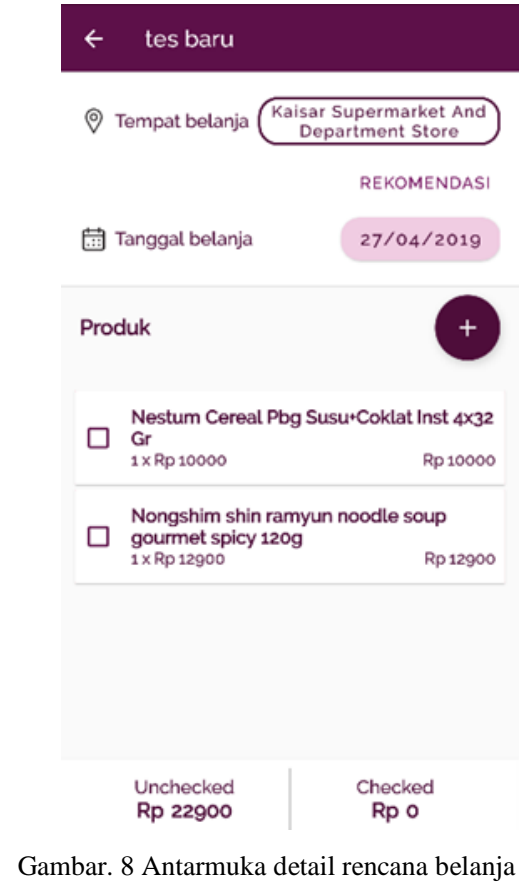

Gambar 9 merupakan tampilan rekomendasi yang secara default diurutkan berdasarkan ketersediaan produk terbanyak, total terendah, dan toko terdekat dengan maksimal jarak $8 \mathrm{~km}$ dari lokasi pengguna. Rekomendasi tersebut kemudian dapat diurutkan dan ditentukan jumlah minimal ketersediaan produk dan jarak maksimal toko rekomendasi dari lokasi pengguna.

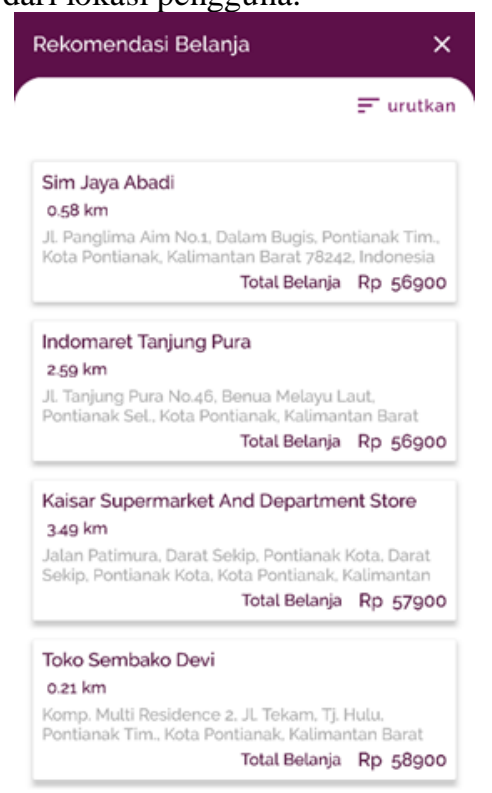

Gambar. 9 Antarmuka rekomendasi harga terendah per total belanja

Gambar 10 merupakan tampilan rekomendasi harga produk terendah. Rekomendasi ini merupakan rekomendasi harga terendah hanya pada satu produk yang dicari oleh pengguna. Rekomendasi harga ini ditampilkan dengan urutan berdasarkan harga terendah dan toko terdekat.

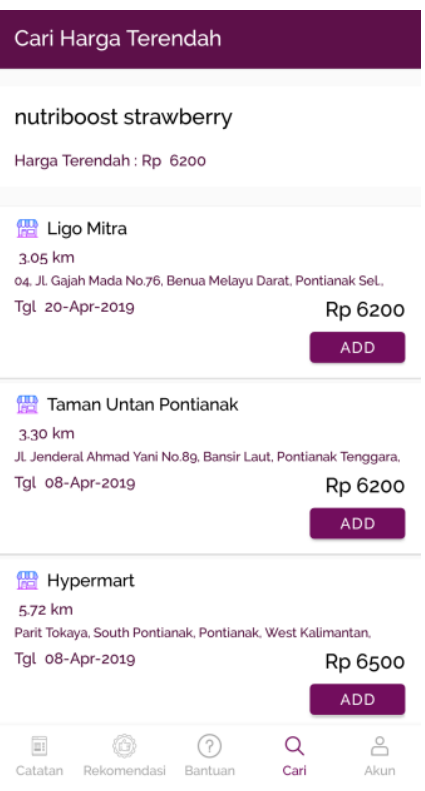

Gambar. 10 Antarmuka rekomendasi harga terendah per produk

\section{F. Hasil Pengujian}

\section{Pengujian Harga Terendah}

Pengujian harga terendah dilakukan dengan membandingkan data riwayat harga yang ada pada basis data dan melihat hasil harga terendah yang ditampilkan pada aplikasi untuk melihat rekomendasi harga yang ditampilkan aplikasi merupakan harga terbaru dan terendah serta terurut berdasarkan toko terdekat jika harga produk sama.

Gambar 11 merupakan data riwayat harga suatu produk yang ada pada basis data.

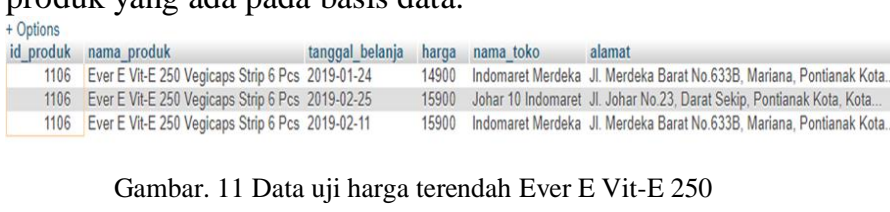

Gambar 12 merupakan data rekomendasi yang ditampilkan pada aplikasi. Data yang ditampilkan pada aplikasi sudah merupakan harga produk terbaru dan terendah serta berurutan berdasarkan jarak terdekat jika harga produk sama.

\section{Pengujian Jarak Terdekat}

Pengujian dilakukan dengan membandingkan antara jarak hasil perhitungan formula haversine dengan jarak hasil perhitungan google maps untuk mendapatkan hasil yang efektif. Perbandingan (Tabel 1) dilakukan dengan menggunakan koordinat default yaitu Gedung Informatika Untan, Pontianak. 


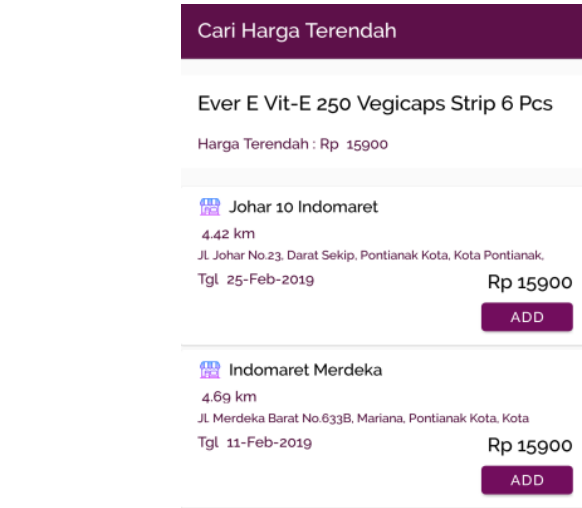

Gambar. 12 Hasil pengujian harga terendah Ever E Vit-E 250 pada aplikasi

TABEL I

Hasil Perbandingan Perhitungan Formula HaVERsine Dengan GOOGLE MAPS

\begin{tabular}{|l|l|l|l|l|}
\hline No & Nama Toko & $\begin{array}{l}\text { Jarak } \\
\text { Haversine } \\
(\mathbf{K m})\end{array}$ & $\begin{array}{l}\text { Jarak } \\
\text { Google } \\
\text { Maps } \\
\mathbf{( K m )}\end{array}$ & Selisih \\
\hline 1 & $\begin{array}{l}\text { Taman Untan } \\
\text { Pontianak }\end{array}$ & 0.33 & 0.05 & 0.28 \\
\hline 2 & $\begin{array}{l}\text { Hypermart Mega } \\
\text { Mall Pontianak }\end{array}$ & 0.39 & 0.55 & 0.16 \\
\hline 3 & $\begin{array}{l}\text { Alma Convenience } \\
\text { Store }\end{array}$ & 0.77 & 0.63 & 0.14 \\
\hline 4 & $\begin{array}{l}\text { Indomaret Sepakat } \\
\text { II }\end{array}$ & 0.78 & 0.59 & 0.19 \\
\hline 5 & $\begin{array}{l}\text { Indomaret Tanjung } \\
\text { Pura }\end{array}$ & 1.97 & 2.00 & 0.03 \\
\hline 6 & Ligo Mitra & 2.45 & 2.56 & 0.11 \\
\hline 7 & $\begin{array}{l}\text { Indomaret Sungai } \\
\text { Raya Dalam 1l/ A2 }\end{array}$ & 2.68 & 2.56 & 0.12 \\
\hline 8 & $\begin{array}{l}\text { Kaisar Supermarket } \\
\text { And Department } \\
\text { Store }\end{array}$ & 3.12 & 3.23 & 0.11 \\
\hline 9 & Sim Jaya Abadi & 3.44 & 3.29 & 015 \\
\hline 10 & Johar 10 Indomaret & 3.57 & 3.75 & 0.18 \\
\hline 11 & INDOMARET Urip & 3.61 & 3.74 & 0.13 \\
\hline 12 & $\begin{array}{l}\text { Indomaret } \\
\text { Alianyang }\end{array}$ & 3.66 & 3.87 & 0.21 \\
\hline 13 & $\begin{array}{l}\text { Indomaret Panglima } \\
\text { Aim }\end{array}$ & 3.58 & 3.44 & 0.14 \\
\hline 14 & Indomaret Merdeka & 4.15 & 4.33 & 0.18 \\
\hline 15 & $\begin{array}{l}\text { Alfamart Gusti Situt } \\
\text { Mahmud }\end{array}$ & 4.67 & 4.61 & 0.06 \\
\hline & & & & \\
\hline
\end{tabular}

\section{Pengujian Bitbar}

Pengujian dengan menggunakan sistem bitbar dilakukan pada tiga perangkat yaitu Google Pixel-US, LG Google Nexus 5 6.0.1, dan LG Google Nexus 5 D820. Berikut ini merupakan hasil pengujian pada perangkat Google Pixel-US.

Gambar 13 merupakan hasil pengujian analisis yang dilakukan oleh sistem bitbar didapatkan hasil 100\%, menyatakan bahwa seluruh metode di dalam aplikasi dapat berjalan. Selanjutnya yaitu pengujian tahapan tanpa mengalami error didapatkan hasil pengujian yaitu 100\% yang menunjukkan seluruh tahapan yang dilakukan aplikasi berjalan tanpa gangguan.

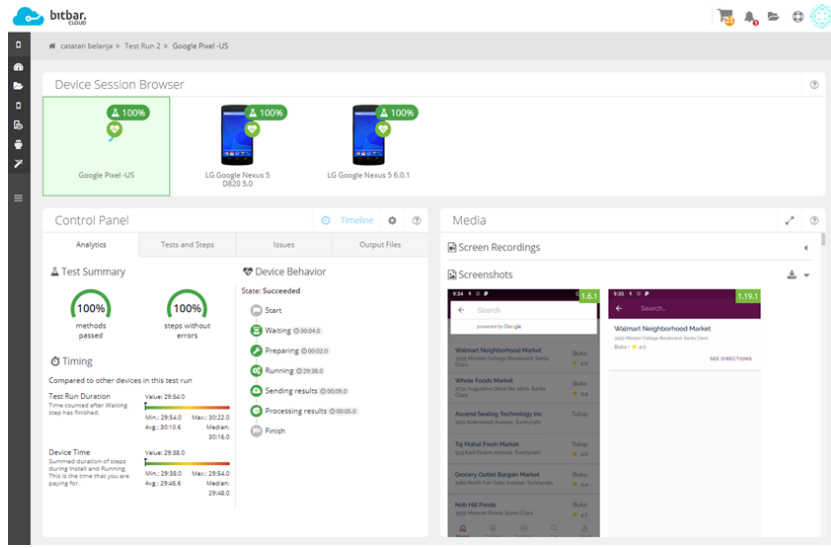

Gambar. 13 Hasil pengujian analisis

Gambar 14 merupakan hasil pengujian performa atau penggunaan $\mathrm{CPU}$.

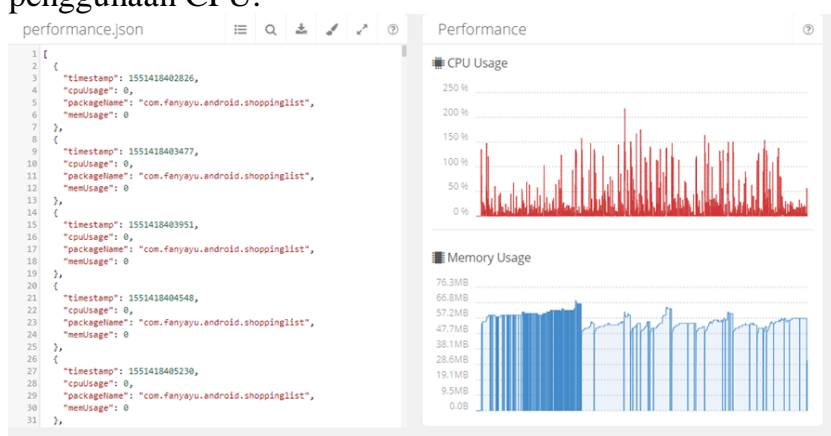

Gambar. 14 Hasil pengujian performa aplikasi

4. Kuesioner

Pengujian kuesioner digunakan menguji tingkat penerimaan pengguna terhadap sistem dengan cara memberikan beberapa pertanyaan tertulis kepada responden untuk dijawab. Kuesioner dibagikan kepada 30 responden yang merupakan pengguna Android. Tabel 2 merupakan total skor dari kuesioner yang telah dibagikan kepada 30 responden.

TABEL II

TOTAL SKOR RESPONDEN DARI KUESIONER

\begin{tabular}{|l|c|c|c|c|c|c|c|c|c|c|c|c|c|c|}
\hline $\begin{array}{l}\text { Resp } \\
\text { onde } \\
\mathbf{n}\end{array}$ & $\mathbf{1}$ & $\mathbf{2}$ & $\mathbf{3}$ & $\mathbf{4}$ & $\mathbf{5}$ & $\mathbf{6}$ & $\mathbf{7}$ & $\mathbf{8}$ & $\mathbf{9}$ & $\mathbf{1}$ & $\mathbf{1}$ & $\mathbf{1}$ & $\mathbf{1}$ & $\begin{array}{c}\text { Tot } \\
\text { al }\end{array}$ \\
\hline 1 & 5 & 5 & 5 & 5 & 5 & 5 & 5 & 5 & 5 & 5 & 5 & 5 & 5 & 65 \\
\hline 2 & 5 & 5 & 5 & 5 & 5 & 5 & 5 & 5 & 5 & 5 & 5 & 5 & 5 & 65 \\
\hline 3 & 5 & 5 & 5 & 5 & 5 & 5 & 5 & 5 & 5 & 5 & 5 & 5 & 5 & 65 \\
\hline 4 & 4 & 4 & 4 & 4 & 4 & 4 & 4 & 4 & 4 & 4 & 4 & 4 & 4 & 52 \\
\hline 5 & 5 & 4 & 5 & 5 & 4 & 4 & 4 & 5 & 4 & 5 & 3 & 4 & 4 & 56 \\
\hline 6 & 5 & 4 & 4 & 5 & 4 & 4 & 4 & 5 & 3 & 5 & 4 & 4 & 5 & 56 \\
\hline 7 & 4 & 4 & 5 & 4 & 3 & 4 & 3 & 4 & 4 & 4 & 4 & 3 & 4 & 50 \\
\hline 8 & 5 & 5 & 5 & 5 & 5 & 5 & 5 & 5 & 5 & 5 & 5 & 5 & 5 & 65 \\
\hline 9 & 5 & 5 & 5 & 5 & 5 & 5 & 5 & 5 & 5 & 5 & 5 & 5 & 5 & 65 \\
\hline 10 & 4 & 4 & 4 & 3 & 4 & 3 & 3 & 3 & 4 & 5 & 3 & 3 & 4 & 47 \\
\hline 11 & 3 & 4 & 4 & 4 & 4 & 4 & 4 & 4 & 4 & 4 & 4 & 4 & 4 & 51 \\
\hline
\end{tabular}




\begin{tabular}{|l|c|c|c|c|c|c|c|c|c|c|c|c|c|c|}
\hline $\begin{array}{l}\text { Resp } \\
\text { onde } \\
\text { n }\end{array}$ & \multicolumn{1}{|c|}{$\mathbf{1}$} & $\mathbf{2}$ & $\mathbf{3}$ & $\mathbf{4}$ & $\mathbf{5}$ & $\mathbf{6}$ & $\mathbf{7}$ & $\mathbf{8}$ & $\mathbf{9}$ & $\mathbf{1}$ & $\mathbf{1}$ & $\mathbf{1}$ & $\mathbf{1}$ & $\begin{array}{c}\text { Tot } \\
\mathbf{a l}\end{array}$ \\
\hline 12 & 5 & 5 & 5 & 4 & 4 & 5 & 4 & 5 & 5 & 5 & 5 & 5 & 5 & 62 \\
\hline 13 & 3 & 4 & 3 & 4 & 4 & 4 & 4 & 4 & 4 & 4 & 4 & 4 & 4 & 50 \\
\hline 14 & 4 & 4 & 5 & 5 & 5 & 5 & 4 & 5 & 5 & 4 & 4 & 5 & 5 & 60 \\
\hline 15 & 5 & 4 & 4 & 5 & 3 & 3 & 4 & 3 & 4 & 4 & 4 & 5 & 4 & 52 \\
\hline 16 & 5 & 4 & 5 & 5 & 5 & 5 & 5 & 4 & 5 & 5 & 5 & 4 & 5 & 62 \\
\hline 17 & 4 & 3 & 4 & 4 & 5 & 3 & 4 & 3 & 5 & 4 & 4 & 4 & 5 & 52 \\
\hline 18 & 5 & 4 & 4 & 4 & 5 & 4 & 5 & 4 & 4 & 4 & 4 & 4 & 4 & 55 \\
\hline 19 & 4 & 4 & 4 & 3 & 3 & 3 & 3 & 3 & 4 & 4 & 4 & 4 & 3 & 46 \\
\hline 20 & 4 & 4 & 5 & 4 & 3 & 4 & 4 & 4 & 3 & 4 & 4 & 3 & 3 & 49 \\
\hline 21 & 4 & 5 & 5 & 5 & 3 & 3 & 4 & 5 & 5 & 4 & 5 & 5 & 5 & 58 \\
\hline 22 & 5 & 5 & 5 & 4 & 5 & 4 & 5 & 4 & 5 & 5 & 4 & 4 & 5 & 60 \\
\hline 23 & 4 & 3 & 5 & 3 & 4 & 3 & 3 & 4 & 5 & 4 & 5 & 4 & 3 & 50 \\
\hline 24 & 5 & 5 & 5 & 4 & 5 & 5 & 5 & 4 & 5 & 5 & 5 & 4 & 5 & 62 \\
\hline 25 & 5 & 5 & 5 & 5 & 5 & 5 & 5 & 5 & 5 & 5 & 5 & 5 & 5 & 65 \\
\hline 26 & 4 & 4 & 5 & 4 & 5 & 4 & 4 & 5 & 4 & 5 & 3 & 4 & 5 & 56 \\
\hline 27 & 5 & 4 & 4 & 5 & 4 & 4 & 4 & 5 & 5 & 5 & 5 & 4 & 5 & 59 \\
\hline 28 & 5 & 4 & 4 & 5 & 4 & 4 & 4 & 5 & 4 & 4 & 5 & 5 & 4 & 57 \\
\hline 29 & 4 & 4 & 4 & 4 & 4 & 4 & 4 & 4 & 5 & 4 & 4 & 4 & 4 & 53 \\
\hline 30 & 5 & 5 & 5 & 4 & 4 & 4 & 4 & 4 & 5 & 4 & 4 & 4 & 4 & 56 \\
\hline & & & & & $T o t a l$ & & & & & 1701 \\
\hline & & & & & & & & & \\
\hline
\end{tabular}

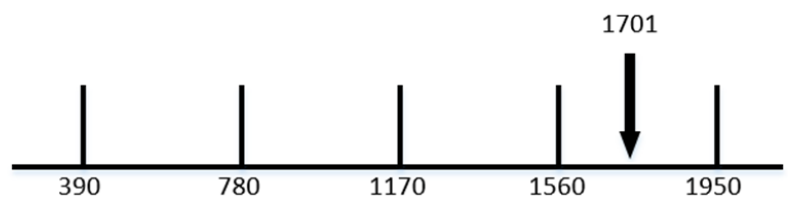

Gambar. 14 Hasil kuesioner pada interpretasi Likert's Summated Rating (LSR)

\section{G. Analisis Hasil Pengujian}

Rincian hasil analisis pengujian aplikasi catatan belanja yang telah dilakukan adalah sebagai berikut:

1. Hasil pengujian fungsional yang dilakukan dengan menggunakan sistem oleh perusahaan Bitbar menunjukkan semua metode yang ada dalam aplikasi dapat berjalan dengan lancar.

2. Hasil pengujian memori dan cpu usage yang dilakukan oleh sistem dari perusahaan Bitbar menunjukkan aplikasi catatan belanja menggunakan banyak memori untuk menjalankan aplikasi.

3. Hasil pengujian jarak terdekat yang dilakukan dengan membandingkan hasil perhitungan formula haversine dan hasil perhitungan jarak Google Maps API menunjukkan bahwa sistem menghasilkan akurasi yang cukup baik dalam menentukan jarak terdekat antara pengguna dan toko.

4. Hasil pengujian harga terendah menunjukkan sistem dapat menampilkan harga produk terendah yang merupakan harga terbaru yang ada pada basis data.
5. Berdasarkan hasil kuesioner, secara umum responden menerima dengan baik aplikasi catatan belanja dalam penelitian yang dilakukan.

6. Hasil pengujian kuesioner yang diukur dengan metode Likert's Summated Rating (LSR) menunjukkan responden menilai aplikasi yang dibagun dengan "sangat baik" dengan skor 1701.

\section{KESIMPULAN}

Berdasarkan hasil analisis dan pengujian terhadap aplikasi catatan belanja untuk menghasilkan rekomendasi harga produk terendah, maka dapat ditarik kesimpulan sebagai berikut:

1. Pendekatan partisipasi masyrakat digunakan untuk mendapatkan data produk yang terbaru berdasarkan catatan belanja tiap pengguna pada aplikasi catatan belanja yang telah dibuat di penelitian ini.

2. Berdasarkan hasil pengujian, aplikasi dapat digunakan untuk melakukan pencatatan belanja dan melihat rekomendasi harga terendah produk dari berbagai toko terdekat. Sistem dapat menghasilkan rekomendasi harga produk terendah yang sesuai dan merupakan harga terbaru yang ada pada basis data. Sistem juga menghasilkan jarak dengan akurasi yang cukup baik dalam menentukan jarak antara pengguna dan toko.

3. Hasil kuesioner yang dihitung dengan metode Likert's Summated Rating menunjukkan responden menilai aplikasi yang dibagun dengan "sangat baik" dengan skor 1701 .

\section{REFERENSI}

[1] Mediakonsumen.com, "Konsumen melakukan Riset Online Meskipun Berbelanja Secara Offline,” 2016. [Online]. Available: https://mediakonsumen.com/2016/09/23/dunia-konsumen/92konsumen-melakukan-riset-online-meskipun-berbelanja-secaraoffline.

[2] Collinsdictionary.com, "Collins English Dictionary," 2018 [Online]. Available: https://www.collinsdictionary.com/dictionary/english/shoppinglist.

[3] P. Nurmi, A. Forsblom, and P. Floréen, "Grocery product recommendations from natural language inputs," in Lecture Notes in Computer Science (including subseries Lecture Notes in Artificial Intelligence and Lecture Notes in Bioinformatics), 2009.

[4] W. Wijaya, Kamus Lengkap Inggris-Indonesia. 2004.

[5] S. Y., Pembangunan Masyarakat Berwawasan Partisipasi. Surakarta: Sebelas Maret University Press, 1994.

[6] O. Soleh, D. Sopiyan, V. Ristiandana, and A. Zaeni, "Aplikasi Pemanfaatan Barcode Untuk Transaksi di Perpustakaan SMAN 18 Kabupaten Tangerang,” Semin. Nas. Sist. Inf. Indones., 2013.

[7] S. Saghranie Daulay, "Hubungan BARCODE dengan Produk Industri Sebagai Standar Perdagangan Produk Industri Masa Kini," 2010.

[8] A. Maurya, "Barcode Reader Using Google Vision Api." [Online]. Available: https://github.com/avaneeshkumarmaurya/BarcodeReader.

[9] R. T. Fielding, "Architectural Styles and the Design of Networkbased Software Architectures," 2000.

[10] L. Richardson and S. Ruby, RESTful Web Services, 1 edition. O'Reilly Media, 2007.

[11] World Wide Web Consortium, "Web Services Architecture," 2004. [Online]. Available: https://www.w3.org/TR/ws-arch/. 
[12] C. J. Su and C. Y. Chiang, "Enabling successful Collaboration 2.0: A REST-based Web Service and Web 2.0 technology oriented information platform for collaborative product development," Comput. Ind., 2012.

[13] W. Setiawan, "Formula Haversine," 2014. [Online]. Available: https://wirasetiawan.blog/2014/08/18/formula-haversine/.

[14] C. Veness, "Calculate distance, bearing and more between Latitude/Longitude points," 2002. [Online]. Available: http://www.movable-type.co.uk/scripts/latlong.html.

[15] Google.com, "Google Places API," Google Developers, 2014 [Online]. Available: https://developers.google.com/places/webservice/search.

[16] Google.com, "Places SDK for Android." [Online]. Available: https://developers.google.com/places/android-sdk/placepicker.

[17] R. A.S and M. Shalahuddin, Rekayasa Perangkat Lunak

Terstruktur dan Berorientasi Objek. Bandung: Informatika, 2014.

[18] Jogiyanto, Analisis Dan Desain Sistem Informasi. Yogyakarta: Andi, 2005 